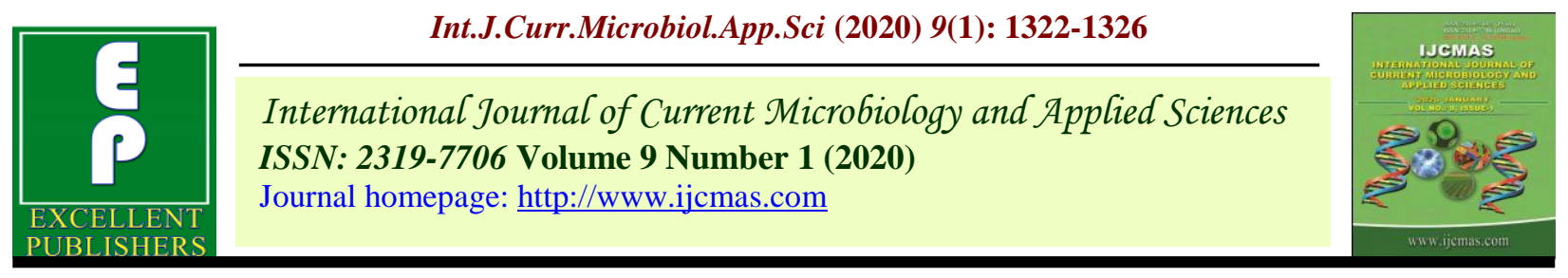

Original Research Article

https://doi.org/10.20546/ijcmas.2020.901.146

\title{
Influence of Terminal Nipping and Growth Regulators on Yield Maximization of Sesame (Sesamum indicum L.)
}

\author{
Y. G. Patil*, H. S. Mahajan, T. R. Patil, M. R. Bedis and S. C. Patil \\ Oilseeds Research Station, MPKV, Jalgaon 425001 (Maharashtra), India \\ *Corresponding author
}

Ke y w o r d s
Sesame, Salicylic
acid, DAP,
Terminal nipping,
Growth and Yield.
Article Info
Accepted:
15 December 2019
Available Online:
20 January 2020

\section{A B S T R A C T}

Afield experiment was conducted during kharif 2018 at Oilseeds Research Station, Jalgaon which comes under Mahatma Phule Agricultural University, Maharashtra state to evaluate the influence of terminal nipping and growth regulators on yield maximization of sesame. The soil of experimental field was vertisoles, low in nitrogen $\left(221 \mathrm{~kg} \mathrm{ha}^{-1}\right)$ medium in phosphorus (21.60 kg ha-1) and rich in potassium $\left(675 \mathrm{~kg} \mathrm{ha}^{-1}\right)$ with alkaline in reaction $(\mathrm{pH}$ 8.14).The experiment was conducted in randomized block design with seven treatments and replicated thrice. The treatment comprises of $\mathrm{T}_{1}$ - Control, $\mathrm{T}_{2^{-}}$Terminal nipping at $30 \mathrm{DAS}, \mathrm{T}_{3}$ Salicylic acid (SA) spray $100 \mathrm{ppm}$ at $30 \mathrm{DAS}, \mathrm{T}_{4}-\mathrm{DAP} 2 \%$ spray at 30DAS, $T_{5}-T_{2}+T_{3}, T_{6}-T_{2}+T_{4}, T_{7}-T_{2}+T_{3}+T_{4}$. Among these treatment $\mathrm{T}_{7}$ i.e. the combination of terminal nipping at $30 \mathrm{DAS}+$ Salicylic acid (SA) spray $100 \mathrm{ppm}$ at $30 \mathrm{DAS}+$ DAP $2 \%$ spray at 30DAS has recorded maximum number of branches plant ${ }^{-1}(5.2)$, number of capsules plant ${ }^{-1}$ (89.7), plant height $(119.56 \mathrm{~cm})$, seed yield $\left(541 \mathrm{~kg} \mathrm{ha}^{-1}\right)$, Net Monitory Return (39210 Rs.ha ${ }^{-1}$ ) and B:C ratio (2.93).

\section{Introduction}

Sesame (Sesamum indicum L.) is an important oilseed crop in the tropics and subtropics belongs to the family pedaliaceae. Because of its excellent oil content quality, it is well known as 'Queen of oilseed crops'. It is the oldest indigenous oil plant with longest history of its cultivation in India. India is the world leader in the area and production of sesame.
Presently, sesame ranks $5^{\text {th }}$ in area (15.80 lakh ha) and $6^{\text {th }}$ in production (7.55 lakh tons) among the nine oilseeds grown countries of the World (Agricultural Statistics at a Glance. 2018). India is still the world leader with the maximum $(25.8 \%)$ production from the largest $(29.8 \%)$ area and highest $(40 \%)$ export of Sesame in the world. The productivity of sesame is low, 3.5-4.5 $\mathrm{q} \mathrm{ha}^{1}$ depending upon the nature of monsoon. Sesame seeds having 
approximately $50 \%$ oil and $25 \%$ protein and contains about $47 \%$ oleic and $39 \%$ linoleic acid. Sesame has remarkable antioxidant function due to the presence of lignins and tocopherol. The oil with $85 \%$ unsaturated fatty acids, is highly stable and has reducing effect on cholesterol and prevents coronary heart diseases. The oil content of sesame is higher than soybean and mustard. To make the country self sufficient in edible oil, it is imperative to increase the production of oilseeds by increasing productivity. The specific reasons identified for the low yield of sesame in India is due to its cultivation under sub marginal land without due importance to the choice of appropriate season and not proper follow the various agronomic practices.

In Maharashtra state, the Sesame crop is grown in kharif and summer seasons. For increasing the seed yield production per hectare could be achieved by adopting improved agronomic practices like proper nutrient management, application of biofertilizers, micronutrients and growth regulators, reorienting of plant structure, reducing field harvesting losses and storage losses. Salicylic acid is a growth regulator which participates in the regulation of physiological processes in plant. The promoting effect of salicylic acid on the leaf area was attributed to its important roles on activating cell division and the biosynthesis of organic foods (Vazirimehr and Rigi, 2014). Similarly, an agronomic practices like terminal bud nipping in sesame crop is one of the important practice for the enhancement of yield and yield attributing parameters. Nipping of terminal bud which activates the dormant lateral buds to produce more branches is an important operation for increasing sesame yield. Nipping practices efficiently alter the crop architecture which in turns increases the lateral branches that lead to greater chances for development of source to sink features in sesame (Ramanathan and Chandrashekharan,
1998). Hence, an experiment was planned to study the influence of terminal nipping and growth regulators on yield maximization of sesame (Sesamum indicum L.).

\section{Materials and Methods}

Afield experiment was conducted on Sesame (cv. JLT-408) at Oilseeds Research Station, MPKV, Jalgaon $\left(21^{\circ} 03^{\prime} \mathrm{N}, 75^{\circ} 34^{\prime} \mathrm{E}, 201.2 \mathrm{~m}\right.$ above mean sea level), during kharif seasons 2018on vertisoles of Maharashtra to study the influence of terminal nipping and growth regulators on yield maximization of sesame (Sesamum indicum L.). The soil of experimental field was clay textured low in nitrogen $\left(221 \mathrm{~kg} \mathrm{ha}^{-1}\right)$ medium in phosphorus $\left(21.60 \mathrm{~kg} \mathrm{ha}^{-1}\right)$ and rich in potassium $(675 \mathrm{~kg}$ $\left.\mathrm{ha}^{-1}\right)$ with alkaline in reaction $(\mathrm{pH} 8.14)$. The average annual rainfall of the region is 750 $\mathrm{mm}$. The experiment was conducted in randomized block design with three replications and total seven treatments comprises $\mathrm{T}_{1}-$ Control, $\mathrm{T}_{2^{-}}$Terminal nipping at 30 DAS, $\mathrm{T}_{3}$ - Salicylic acid (SA) spray100ppm at 30 DAS, $\mathrm{T}_{4}-\mathrm{DAP} 2 \%$ spray at $30 \mathrm{DAST}_{5}-\mathrm{T}_{2}+$ $\mathrm{T}_{3}, \mathrm{~T}_{6^{-}} \mathrm{T}_{2}+\mathrm{T}_{4}, \mathrm{~T}_{7^{-}} \mathrm{T}_{2}+\mathrm{T}_{3}+\mathrm{T}_{4}$. The sesame variety JLT-408 was sown with $2.5 \mathrm{~kg}$ seed $\mathrm{ha}^{-1}$ in $45 \mathrm{~cm}$ apart and $10 \mathrm{~cm}$ plant to plant by thinning twice at $7^{\text {th }}$ and $21^{\text {th }}$ days after sowing. Gross plot size was $5.0 \times 4.50 \mathrm{~m}$ and net plot size was $4.0 \times 3.60 \mathrm{~m}$. The crop was fertilized with recommended dose of nitrogen $50 \mathrm{~kg} \mathrm{ha}^{-1}$. Half dose of $\mathrm{N}$ was applied as basal at the time of sowing and remaining half dose of $\mathrm{N}$ after 3 weeks of sowing. In order to represent the plot, five plants of sesame from each plot were selected randomly and labeled properly. The growth attributing characters viz. plant height $(\mathrm{cm})$, number of branches plant ${ }^{-1}$ were recorded and at the time of harvest yield and yield attributing characters viz. number of capsulesplant $^{-1}$, seed yield $\mathrm{kg} \mathrm{ha}{ }^{-1}$ were recorded. Economics of the each treatment was calculated as per the prevailing market rates and net returns and $\mathrm{B}: \mathrm{C}$ ratio was 
calculated. All the data were subjected to the analysis of variance (ANOVA) as per the standard procedure (Gomez and Gomez, 1984).

\section{Results and Discussion}

\section{Effect on growth and yield}

Data of this study revealed that, growth parameters of sesame like plant height, number of branches plant ${ }^{-1}$ and number of capsules plant ${ }^{-1}$ significantly influenced under different treatments (Table 1). The treatment $\mathrm{T}_{7}$ i.e the combination of terminal nipping at 30 DAS + Salicylic acid (SA) spray100 ppm at 30 DAS + DAP $2 \%$ spray at 30DAS noticed significantly higher plant height $(119.56 \mathrm{~cm})$, number of branches plant ${ }^{-1}$ (5.2), number of capsules plant $^{-1}(89.7)$ ancillary traits over rest of treatments. However, the plant height was relatively more at all the stages of growth in non-nipped plants with all Salicylic acid and DAP 2\% sprays compared to control plot. Similar results were observed by Kathiresan and Duraisamy (2001), Siddagangamma et al., (2018) and Vasanthan et al., (2019). In the present investigation, in sesame crop it was found that nipping of the terminal bud activates the dormant lateral buds for producing more branches and ultimately the seed yield was increased. Nipping changes both morphology and physiology of plants. Similarly, the increased number of flowers and capsules were due to the effect of salicylic acid on physiological process such as cell division, ion uptake, enzyme activities, and photosynthetic activity.

The $\mathrm{T}_{7}$ i.e. the combination of terminal nipping at 30 DAS + Salicylic acid (SA) spray 100ppm at 30 DAS + DAP 2\%spray at 30DASsignificantly increased the yield and yield attributing characters like number of capsule, seed yield per capsule and seed yield per hector. The maximum seed yield $(541 \mathrm{~kg}$ $\mathrm{ha}^{-1}$ ) recorded in treatment $\mathrm{T}_{7}$. Foliar application of Salicylic acid and DAP 2\% had further improvement on plant photosynthesis and it was evident when plants were sprayed with salicylic acid. The increase in yield was 27 per cent over the control, which might be due to increase in translocation of photosynthates with the combination of terminal nipping, Salicylic acid and DAP 2\% treatment. Similar results evidenced by Suvitha et al., (2018), Siddagangamma et al., (2018) and Vasanthan et al., (2019).

\section{Economics}

The ultimate aim of addition of any inputs, whether it is cash or farm produced input, depends on how far it is profitable. The economics of different treatments were determined by considering the cost of inputs used and gross returns (Table 2). From the data revealed that the economics of the treatments $\mathrm{T}_{7}$ i.e. the combination of terminal nipping at 30 DAS + Salicylic acid (SA) spray100ppm at 30 DAS + DAP $2 \%$ spray at 30DASwas influenced. The highest gross monetary return of (Rs.59510ha ${ }^{-1}$ ), net returns (Rs.39210 ha ${ }^{-1}$ ) and $\mathrm{B}: \mathrm{C}$ ratio of 2.93 was observed in treatments $\mathrm{T}_{7}$ over other treatments, which was followed by the treatment $\mathrm{T}_{6}$ i.e. the combination of terminal nipping at $30 \mathrm{DAS}+$ DAP $2 \%$ spray at 30DAS(Rs58080 ha ${ }^{-1}$, Rs37880 ha ${ }^{-1}$ and 2.88 respectively) which is at par. The similar results regarding gross return, net return and $\mathrm{B}: \mathrm{C}$ ratio with combination of plant geometry and foliar application were also observed by Suvitha et al., (2018).

It can be concluded that for an optimum productivity and profitability of sesame under rainfed conditions the preference should be given to the application of terminal bud nipping at 30 DAS with the spray of Salicylic acid (SA) $100 \mathrm{ppm}$ and DAP 2\%spray at 30DAS. 
Table.1 Effect of terminal nipping and growth regulators on growth attributing character and yield attributing characters

\begin{tabular}{|l|l|l|l|l|l|}
\hline Sr.No. & Treatment details & $\begin{array}{l}\text { No. } \\
\text { branches }_{\text {plant }^{-1}}\end{array}$ & $\begin{array}{l}\text { of } \\
\text { Plant } \\
\text { height } \\
\text { (cm) }\end{array}$ & $\begin{array}{l}\text { No. of } \\
\text { capsules }_{\text {plant }^{-1}}\end{array}$ & $\begin{array}{l}\text { Seed yield } \\
\left.\text { (kg ha }^{-1}\right)\end{array}$ \\
\hline $\mathbf{1}$ & $\mathrm{T}_{1}$-Control & 3.8 & 105.56 & 71.7 & 425 \\
\hline $\mathbf{2}$ & $\begin{array}{l}\mathrm{T}_{2} \text {-Terminal nipping at 30 } \\
\text { DAS }\end{array}$ & 4.1 & 106.33 & 81.0 & 451 \\
\hline $\mathbf{3}$ & $\begin{array}{l}\mathrm{T}_{3} \text {-Salicylic acid (SA) } \\
\text { spray100ppm at 30 DAS }\end{array}$ & 3.8 & 108.56 & 79.3 & 435 \\
\hline $\mathbf{4}$ & $\mathrm{T}_{4}-\mathrm{DAP}$ \%spray at 30DAS & 3.9 & 118.17 & 89.0 & 438 \\
\hline $\mathbf{5}$ & $\mathrm{T}_{5}-\mathrm{T}_{2}+\mathrm{T}_{3}$ & 4.5 & 113.00 & 85.7 & 464 \\
\hline $\mathbf{6}$ & $\mathrm{T}_{6}-\mathrm{T}_{2}+\mathrm{T}_{4}$ & 4.0 & 115.33 & 86.3 & 528 \\
\hline $\mathbf{7}$ & $\mathrm{T}_{7}-\mathrm{T}_{2}+\mathrm{T}_{3}+\mathrm{T}_{4}$ & 5.2 & 119.56 & 89.7 & 541 \\
\hline & $\mathrm{SE}_{ \pm}$ & 0.28 & 5.33 & 3.78 & 18.10 \\
\hline & $\mathrm{CD}$ at 5\% & 0.82 & 17.17 & 11.66 & 56.11 \\
\hline
\end{tabular}

Table.2 Effect of terminal nipping and growth regulators on GMR, Cost of cultivation, NMR and $\mathrm{B}: \mathrm{C}$ ratio.

\begin{tabular}{|c|c|c|c|c|c|}
\hline S.No. & Treatment details & $\begin{array}{c}\text { Gross } \\
\text { monetary } \\
\text { returns } \\
\left(\text { Rs. ha } \text { ha }^{-1}\right)\end{array}$ & $\begin{array}{c}\text { Cost of } \\
\text { cultivation } \\
\left(\text { Rs. ha' }{ }^{-1}\right)\end{array}$ & $\begin{array}{c}\text { Net } \\
\text { monetary } \\
\text { returns } \\
\left(\text { Rs. } \text { ha }^{-1}\right)\end{array}$ & $\begin{array}{c}\text { B:C } \\
\text { Ratio }\end{array}$ \\
\hline 1 & $\mathrm{~T}_{1}$-Control & 46750 & 19100 & 27650 & 2.45 \\
\hline 2 & $\begin{array}{l}T_{2} \text {-Terminal nipping at } 30 \\
\text { DAS }\end{array}$ & 49610 & 19950 & 29660 & 2.49 \\
\hline 3 & $\begin{array}{l}\mathrm{T}_{3} \text {-Salicylic acid (SA) } \\
\text { spray100ppm at } 30 \text { DAS }\end{array}$ & 47850 & 20300 & 27550 & 2.36 \\
\hline 4 & $\mathrm{~T}_{4}$-DAP $2 \%$ spray at 30DAS & 48180 & 19350 & 28830 & 2.49 \\
\hline 5 & $\mathrm{~T}_{5}-\mathrm{T}_{2}+\mathrm{T}_{3}$ & 51040 & 20300 & 30740 & 2.51 \\
\hline 6 & $\mathrm{~T}_{6}-\mathrm{T}_{2}+\mathrm{T}_{4}$ & 58080 & 20200 & 37880 & 2.88 \\
\hline 7 & $\mathrm{~T}_{7}-\mathrm{T}_{2}+\mathrm{T}_{3}+\mathrm{T}_{4}$ & 59510 & 20300 & 39210 & 2.93 \\
\hline 8 & $\mathrm{SE}_{ \pm}$ & - & - & 872 & 0.10 \\
\hline 9 & $\mathrm{CD}$ at $5 \%$ & - & - & 2747 & 0.31 \\
\hline
\end{tabular}

\section{References}

Agricultural Statistics Data. 2018. Department of Agriculture and
Cooperation, Ministry of Agriculture, Govt. of India. https://eands.dacnet.nic.in/ 
Gomez, K. A. and Gomez, A. A. 1984. Statistical Procedures for Agricultural Research. Edn 2. Wiely Inter Science Publications and John Willy and Sons, New York.

Kathiresan, G., 1999. Effect of growth regulators and clipping on sesame growth and yield in different seasons. Sesame and Safflower Newsl. 14 :46-49.

Kathiresan, G., Duraisamy K. 2001. Effect of clipping and diammonium phosphate spray on growth and seed yield of dhaincha (Sesbania aculeata). Indian $J$ Agron. 46(3): 568-572.

Ramanathan, S.P and B. Chandrashekharan, 1998. Effect of nipping plant geometry and fertilizer on summer sesame. Indian Journal of Agronomy. 43 (2): 329-332.

Siddagangamma, K.R., A.A. Choudhary, S.N. Potkile, D.G. Sonuneand M.P. Punse. 2018. Effect of terminal bud nipping and salicylic acid spray on growth and yield of sesame. Journal of Soils and Crops. 28(1): 216-220.

Suvitha R., Joseph M., Hemalatha M., Senthil A. and Bharathi G., 2018. Effect of plant geometry and nutrient management practices on growth and yield of Sesame (Sesamum indicumL.) under rainfed vertisol. International $J$. Agril. Sci. 10(13): 6543-6546.

Vasanthan V, R. Geeths, C. Menaka, V. Vakeswaran and C. Parameswari. 2019. Study on effect of nipping and foliar spray on seed yield of sesame var. TMV 7. International Journal of Chemical Studies. 7(3): 4180-4183.

Vazirimehr, M.R. and K. Rigi. 2014. Effect of salicylic acid in agriculture. International Journal of Plant, Animal and Envir. Sci. 291-296. https://www.rroij.com.

\section{How to cite this article:}

Patil Y.G., H. S. Mahajan, T. R. Patil, M. R. Bedis and Patil S.C. 2020. Influence of terminal nipping and growth regulators on yield maximization of Sesame (Sesamum indicum L.). Int.J.Curr.Microbiol.App.Sci. 9(01): 1322-1326. doi: https://doi.org/10.20546/ijcmas.2020.901.146 